\title{
Stylistyka wnętrz historycznych budynków położonych w wybranych miejscowościach uzdrowiskowych na Huculszczyźnie - zarys problematyki
}

\author{
Jacek Czubiński \\ https://orcid.org/0000-0002-0661-7760 \\ jacek.czubinski@pk.edu.pl \\ Instytut Historii Architektury i Konserwacji Zabytków, Politechnika Krakowska
}

\begin{abstract}
Streszczenie: W miejscowościach uzdrowiskowych położonych w dolinie Prutu na Huculszczyźnie zachował się duży, niezwykle interesujący, zespół obiektów powstałych w okresie międzywojennym. Związane są one zarówno z architekturą modernistyczną jak i nurtami regionalnymi. Praca przedstawia i analizuje wybrane przykłady aranżacji wnętrz reprezentujących te dwie tendencje. Zagadnienie to było niemal całkowicie pominięte w dotychczasowych badaniach nad architekturą tego regionu. Prowadzone przez autora studia terenowe i archiwalne pozwoliły zidentyfikować szereg projektów i realizacji. Badania będą kontynuowane w przyszłości.
\end{abstract}

Słowa kluczowe: architektura uzdrowiskowa, Huculszczyzna, Jaremcze, wnętrza historyczne, Worochta

\section{Wprowadzenie, stan badań i metoda}

W miejscowościach uzdrowiskowych położonych w dolinie Prutu na Huculszczyźnie zachował się duży, niezwykle interesujący, zespół obiektów powstałych w okresie międzywojennym ${ }^{1}$. W pracy przeprowadzono analizę wybranych wnętrz historycznych znajdujących się w historycznych budynkach o różnych funkcjach oraz reprezentujących odmienne tendencje stylistyczne. Przykłady dotyczą obiektów pensjonatowych oraz użyteczności publicznej, w tym gastronomicznych. Formalnie związane są one zarówno z modernizmem międzywojennym jak i nurtami regionalnymi. Należy podkreślić, że ta druga tendencja dominowała w architekturze regionu. Natomiast różne odmiany modernizmu wytworzyły na tym terenie bardzo interesującą lokalną odmianę ${ }^{2}$. Praca nie wyczerpuje tematu, planowane jest rozszerzenie badań na inne obiekty.

Omawiane zagadnienie nie było dotychczas przedmiotem głębszych studiów i analiz. Fragmentaryczne informacje pojawiają się w nielicznych pracach związanych z poszczególnymi obiektami ${ }^{3}$. Cennych informacji

1 Za miejscowości uzdrowiskowe doliny Prutu na Huculszczyźnie należy uważać: Delatyń, Jaremcze (z Dorą i Jamnem), Mikuliczyn, Tatarów oraz Worochtę.

2 J. Czubiński, Nurt modernizmu w międzywojennej architekturze miejscowości uzdrowiskowych położonych w dolinie rzeki Prut na Huculszczyźnie, [w:] Modernizm w Europie - Modernizm w Gdyni. Tom V, Gdynia 2018, s. 103-108.

3 Przykładowo: W. Drohobycka-Grzesiak, Architektura uzdrowisk wschodniokarpackich w okresie międzywojennym i jej stan obecny (na postawie wybranych przykładów), [w:] Architektura XX wieku i jej waloryzacja w Gdyni i w Europie. Modernizm w Europie, Modernizm w Gdyni. Tom 4, Gdynia 2017, s. 157-162. Także: J. Czubiński, "Straszny Dwór” (Haunted Manor) guesthouse in Tatarów in the Hutsul region and its designer Jerzy Romaszkan, "Teka Komisji Architektury, Urbanistyki i Studiów Krajobrazowych”, t. 13, nr 3, Lublin 2017, s. 67-77. Państwowe Archiwum Iwano-Frankiwskiej Oblastii w Iwano-Frankiwsku (dalej DAIFO). 
dostarcza lektura także niezbyt bogatej literatury przedmiotu ${ }^{4}$ i źródeł (np. wspomnień i pamiętników, przewodników, folderów i czasopism) z epoki oraz analiza fotografii archiwalnych, publikowanych lub przechowywanych w zbiorach prywatnych ${ }^{5}$. Duży, lecz zdekompletowany zasób oryginalnych projektów architektonicznych przechowywany jest w archiwum w Iwano-Frankiwsku ${ }^{6}$. W pracy są używane nazwy budynków z okresu międzywojennego, natomiast ich adresach pojawia się współczesne nazewnictwo ulic.

Niniejsza praca oparta jest głównie na studiach terenowych oraz analizie literatury i materiałów źródłowych. W latach 2007-2019 studenci i pracownicy Wydziałów Architektury Politechniki Krakowskiej (PK) oraz Państwowego Uniwersytetu Technicznego Nafty i Gazu w Iwano-Frankiwsku (DTUNiG) prowadzili badania nad historyczną architekturą i wykonywali inwentaryzacje rysunkowe wybranych obiektów na terenie miejscowości Jaremcze, Worochta i Tatarów położonych w dolinie Prutu na Huculszczyźnie. Inwentaryzacje te oraz analiza porównawcza zebranej ikonografii historycznej i współczesnej pozwoliły określić stopień oryginalność i przekształceń obiektów. Zakres pracy ograniczony został terytorialnie do dwóch ostatnich miejscowości, czasowo obejmuje okres międzywojenny z koniecznymi odniesieniami w przeszłość.
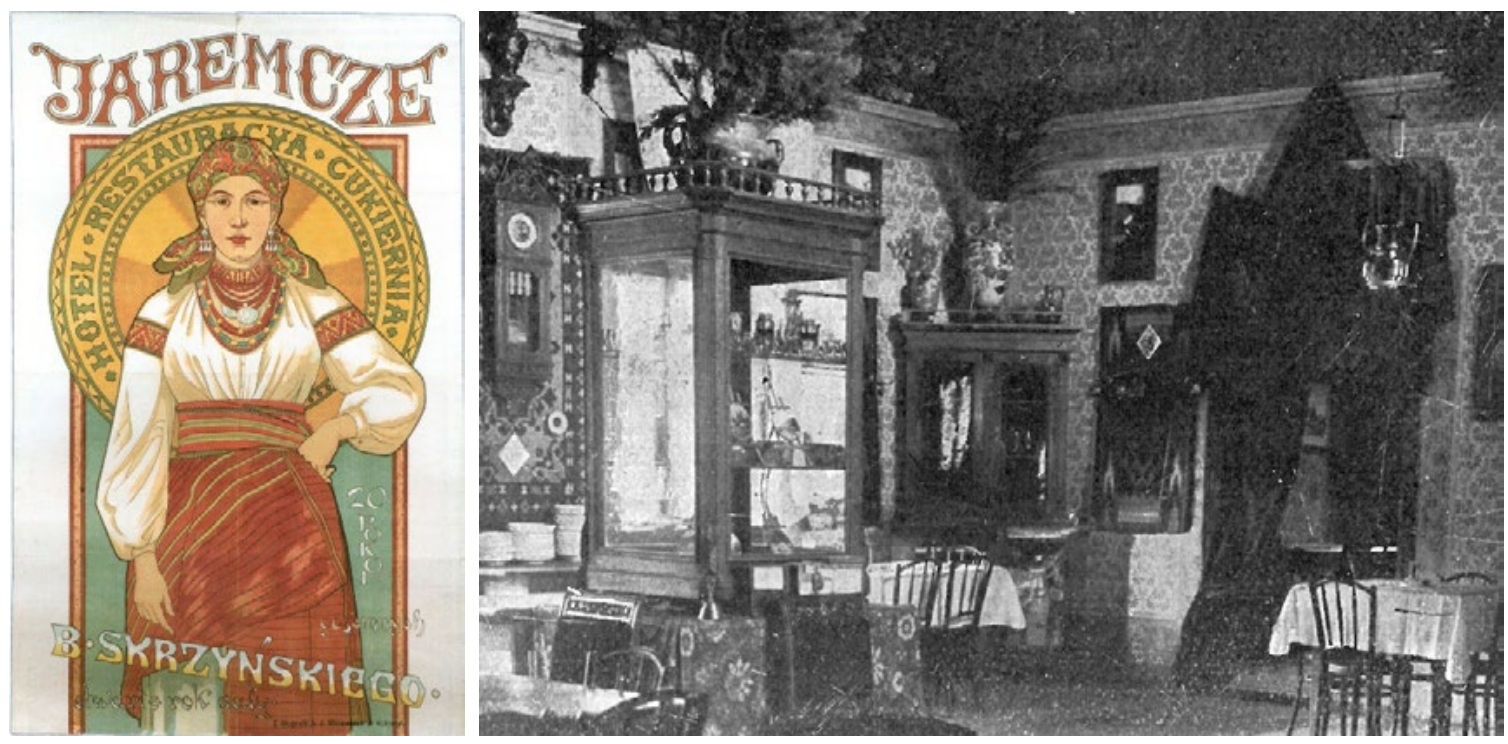

Ryc. 1. Plakat reklamujący hotel, restaurację i cukiernię B. Skrzyńskiego w Jaremczu z około 1910 r. Reprodukcja w zbiorach autora

Ryc. 2. Sala w restauracji Skrzyńskiego w Jaremczu. Źródło: Lewicki St. A., Orłowicz M., Praschil T., Przewodnik po zdrojowiskach i miejscowościach klimatycznych Galicyi, Lwów 1912, s. 62

\section{Wybrane przykłady wnętrz historycznych}

Poniżej zostanie przedstawiona analiza reprezentatywnych dla tematu wnętrz historycznych. Ich wybór podyktowany został zakresem wykonanych badań terenowych oraz dostępnością ikonografii i materiałów archiwalnych. Pierwsza grupa omawianych obiektów związana jest z działalnością gastronomiczną.

Ogłoszenie, które ukazało się w 1937 r. we Iwowskich „Wiadomościach Turystycznych" tak zachęcało do przyjazdu do Jaremcza: Jaremcze. Uzdrowisko górskie praz solankowy zakład kąielowy $i$ inhalacyjny w dolinie Prutu (525 m n.p.m.). Dworki huculskie i komfortowe pensjonaty. Piękne wycieczki wysokogórskie. Ceny b. przystępne.

4 Przykładowo: S. Niecieja, Kresowa Atlantyda. Historia i mitologia miast kresowych. T. II. Uzdrowiska i letniska kresowe. Truskawiec, Jaremcze, Worochta, Skole, Morszyn, Opole 2013, s. 93-162.Także ponad dwadzieścia prac naukowych opublikowanych przez autora niniejszego artykułu.

5 Przykładowo: Zbiory Krystyny Petrowicz-Szopa, [w:] http://www.wiki.ormianie.pl/index.php?title=Kajetan_Petrowicz_syn_Marko [dostęp 21.07.2020].

6 „Wiadomości Turystyczne", 1.06.1937, rok VII, nr 11, s. 2. 
Sezon trwa caty rok. Pierwszorzędne lokale rozrywkowe. Informacje: Komisja Uzdrowiskowa w Jaremczu. Stacja kol., poczta, telegraf i telefon na miejscu. Zwrócono w nim uwagę, że oprócz walorów leczniczo-turystycznych istotną rolę w działalności tej miejscowości spełniają lokale rozrywkowo-gastronomiczne - restauracje, bary i dancingi. Posiadały one niejednokrotnie interesujący wyraz architektoniczny i aranżacje wnętrz. W miejscowościach uzdrowiskowych zwykle prowadziło działalność wiele różnego typu zakładów gastronomicznych. Czasami zlokalizowane były w pensjonatach, niejednokrotnie funkcjonowały niezależnie, jako obiekty wolnostojące. Przed I wojną światową w Jaremczu do najbardziej popularnych należały m.in.: restauracja w pensjonacie "Dwór", restauracja hotelu "Hanusa" i hotelu "Krakowskiego" oraz restauracja i cukiernia Skrzyńskiego. W okresie międzywojennym renomę zyskała m.in. restauracja i bar "Pod Wodosapdem”, tzw. „Lankoszówka”.

Do 1914 r. jednym z najbardziej prestiżowym miejscem spotkań w Jaremczu była, usytuowana naprzeciw dworca kolejowego, restauracja i cukiernia należąca do Bolesława Skrzyńskiego ${ }^{7}$ (Ryc. 1). Niewielki parterowy obiekt ze słupowym portykiem wejściowym i obszerną werandą przykryty był dwuspadowym dachem naczółkowym. Wyróżniał się smukłą wieżą w narożniku. Przewodnik z 1912 roku tak opisuję to miejsce Restauracja Skrzyńskiego naprzeciw dworca z obszerna bardzo gustownie udekorowanq sala jadalniana i wielka ocieniona werandą. Co dzień wieczorem koncert muzyki ze Stanisławowa. W tej restauracji jest cukiernia. Całodzienny wikt od 4 koron. ${ }^{8}$ Zarówno restauracja jak i pobliski, należący także do Skrzyńskiego hotel, zostały przy innej okazji ocenione jako "bardzo gustownie urządzone" ${ }^{\prime 9}$. Fotografia zamieszczona we wspomnianym przewodniku pozwala nam na unaocznienie opisu (Ryc. 2$)^{10}$. Jest to najstarszy znany autorowi materiał ikonograficzny z tego regionu prezentujący wygląd wnętrza. Wystrój pomieszczenia odzwierciedlał epokę. Ściany, pokryte tapetami z młodopolskim ornamentem geometrycznym, zwieńczono fryzem z profilowanym gzymsem podsufitowym. Sala wyposażona była w meble o formach zarówno historycznych jak i secesyjnych. Całość utrzymano w atmosferze mieszczańskiego salonu.

Restauracja ta została zniszczona w trakcie I wojny światowej. Po jej zakończeniu mieściła się w nowo zbudowanym, usytuowanym obok poprzedniej lokalizacji, parterowym obiekcie o dwuspadowym dachu z kalenicą prostopadłą do drogi ${ }^{11}$. W 1933 r. dobudowano do niego od zachodu, od strony głównej drogi, salę restauracyjną ${ }^{12}$. Nowa część była parterowym, prostokątnym w rzucie budynkiem o formach modernistycznych. Horyzontalna kompozycja bryły o płaskich dachach zdominowana została frontowym portykiem słupowym ${ }^{13}$. Ponad dachem parteru pojawił się prostopadłościenny świetlik z oknami doświetlającymi salę restauracyjną. Wkrótce, bo już w 1934 roku, przystąpiono do kolejnej rozbudowy restauracji ${ }^{14}$. Powstało wtedy, na miejscu wspomnianego "starego" obiektu z dwuspadowym dachem, piętrowe zaplecze kuchenne dla restauracji. Utrzymano je także w formach modernistycznych. Autorem tego projektu sporządzonego dla Marii ze Skrzyńskich Goertzowej był inż. Gustaw Weitzmann ze Stanisławowa ${ }^{15}$. Nie zakończyło to procesu rozbudowy restauracji o nazwie „B. Skrzyński. Restauracja-Bar-Dancing”. W drugiej połowie lat 30. dobudowano do zachodniej fasady budynku nową siedmiokątną część na planie zbliżonym do półkola z szerokim tarasem osłoniętym okapem ${ }^{16}$ (Ryc. 3). Układ jej rzutu i ogólna dyspozycja przestrzenna wykazuje dużą analogię z omawianym poniżej, powstałym w 1936 r. budynkiem Baru Lankosza w Jaremczu-Jamna. Na tej podstawie autorstwo projektu rozbudowy można z dużym prawdopodobieństwem przypisać Maxymilianowi Platzerowi.

7 Mieściła się ona w budynku powstałym po 1900 r. obok istniejącego wcześniej hotelu prowadzonego przez tego samego właściciela Budynek hotelu widnieje na pocztówce wydanej przed $1900 \mathrm{r}$.

8 St. A. Lewicki, M. Orłowicz, T. Praschil, Przewodnik po zdrojowiskach i miejscowościach klimatycznych Galicyi, Lwów 1912, s. 61-62.

9 Miejscowość klimatyczna "Jaremcze”, Lwów 1913, s. 10.

10 St. A. Lewicki..., op. cit., s. 62.

11 Nie udało się odnaleźć materiałów ikonograficznych związanych z tym budynkiem. Fragment dachu tego obiektu widoczny jest na pocztówce z około 1934 r.

12 Zezwolenie na budowę sali restauracyjnej udzielono 24.10 .1933 oraz ostatecznie 30.12.1933 r. DAIFO, sygn. 2/1e-8/ 2331.

13 Por.: W. Drohobycka-Grzesiak, Architektura uzdrowisk..., op. cit., s. 160-161.

14 Prośba o przebudowę parteru i nadbudowę budynku przylegającego od wschodu do istniejącej sali restauracyjnej z dnia 5.06 .1934 r. (była to faktycznie budowa nowego obiektu). DAIFO, sygn. 2/1e-8/2331.

15 DAIFO, sygn. 2/1e-8/2331.

16 Był to bardzo popularny w tym czasie motyw „stylu okrętowego". Daje się zauważyć podobieństwo z powstałym w 1936 r. pawilonem gastronomicznym browaru w Okocimiu (tzw. „pawilon okocimski”) zlokalizowanym w Lesie Wolskim w Krakowie. Jego autorem był arch Jan Ogłódek. Obiekt ten charakteryzuje się półkolistym zamknięciem sali restauracyjnej oraz wydatnym, wspartym na słupach, okapem nad tarasem. [w:] Historia Pawilonu Okocimskiego na Polanie Lea w Lesie Wolskim, https://symbioza-krakow.pl/historia/ [dostęp 02.04.2020]. 


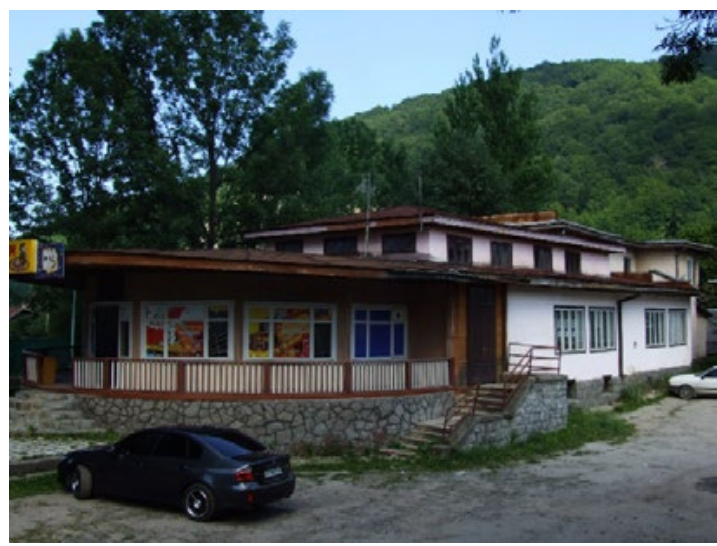

Ryc. 3. Jaremcze. Budynek dawnej Restauracja Skrzyńskiego. Widok od południowego-zachodu. Stan obecny, po rozbudowach z 1933 r. oraz z końca lat 30. XX w. Ponad gzymsem parteru widoczny jest świetlik sali restauracyjnej (Fotografia autora, 2005 r.)

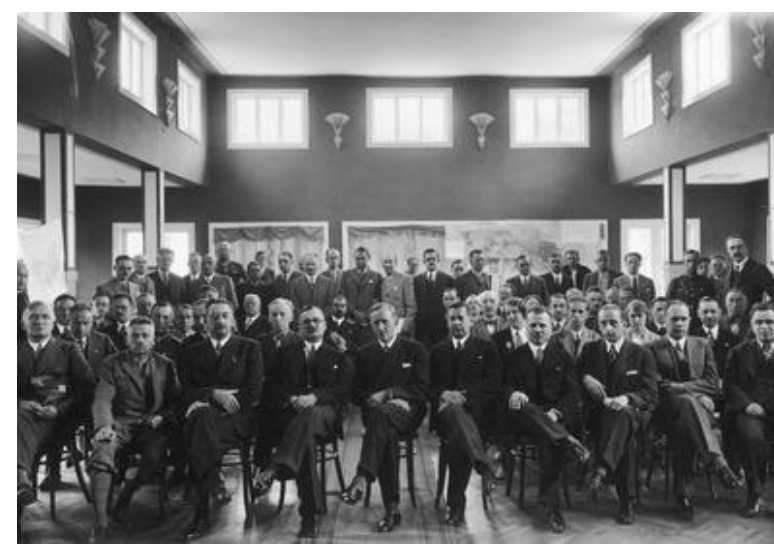

Ryc. 4. Jaremcze. Dawna restauracja Skrzyńskiego. Widoczne wnętrze sali restauracyjnej z uczestnikami Zjazdu Turystyczno-Uzdrowiskowego w Jaremczu w 1934 r. Na wysokości drugiej kondygnacji widoczne są okna świetlika (NAC, sygnatura: $3 / 1 / 0 / 14 / 3589 / 1)$

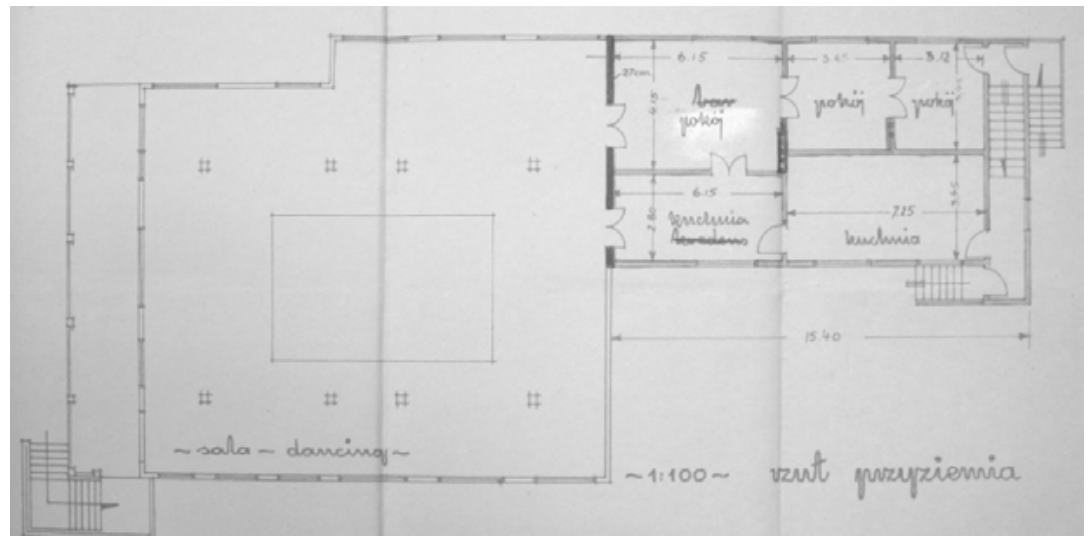

Ryc. 5. Jaremcze. Dawna restauracja Skrzyńskiego. Projekt przebudowy części wschodniej z 1934 r., rzut przyziemia. Po lewej stronie sala restauracyjna (dancingowa) ze slupami podtrzymującymi świetlik i portykiem od frontu. Autor: inż. Gustaw Weitzmann (DAIFO, sygn. 2/1e-8/2331)

Zachowały się fotografie wnętrza restauracji Skrzyńskiego wykonane w trakcie Zjazdu Turystyczno-Uzdrowiskowego w Jaremczu w 1934 r. Jedna z nich przedstawia uczestników tego wydarzenia pozujących do zdjęcia zbiorowego w sali restauracyjnej (Ryc. 4$)^{17}$. Analizując tę fotografię oraz oryginalny rzut przyziemia projektu rozbudowy wykonany przez wspomnianego inż. G. Weitzmanna (Ryc. 5) w 1933 r. oraz porównując ten materiał ze współcześnie wykonanymi rysunkami inwentaryzacyjnymi obiektu (Ryc. 6, 7) można odtworzyć pierwotny wyraz architektoniczny wnętrza ${ }^{18}$. Wysoka, wsparta na słupach, centralna przestrzeń sali flankowana była od południa i północy niższymi aneksami tworząc bazylikowy układu przestrzeni. Oświetlenie wnętrza zapewniały okna w parterze oraz okna umieszczone w górnej strefie pomieszczenia tworzącej rodzaj świetlika. Lapidarny charakter wnętrza nasuwa skojarzenie z modernistyczną architekturą funkcjonalną. Geometryczna kompozycja całości podkreślona została gładkimi płaszczyznami ścian o zdecydowanych, nierozpoznanych, kolorach kontrastujących z bielą sufitów. Jedynymi elementami ocieplającymi surowość wnętrza były kinkiety, rodem ze stylistyki art déco, umieszczone na ścianach pomiędzy oknami świetlika.

Bazylikowy układ przestrzenny wnętrza restauracyjnego z wysoką częścią centralną i niższymi aneksami bocznymi rozpoznano $w$ dwóch innych projektach budynków w Jaremczu-Jamna. Z tego tylko jeden został 
zrealizowany. Obydwa wiążą się z inwestycjami prowadzonymi przez rodzinę Lankoszów na parceli położonej pomiędzy Prutem a torami kolejowymi, obok przystanku kolejowego Jaremcze-Kamień Dobosza. Pierwsza restauracja Lankosza powstała przed rokiem 1913. Świadczy o tym opis atrakcji Jaremcza pochodzący z tego roku Restauracja p. Lankosza w pięknym potożeniu, nad wodospadem Prutu. $2 \mathrm{~km}$ od dworca kolejowego gościńcem w kierunku Mikuliczyna. Park, kręgielnia, strzelnica i 6 pokoi hotelowych ${ }^{19}$. Przed rokiem 1930 na działce obok restauracji zlokalizowane były inne budynki, niewielki pensjonat, kręgielnia oraz budynek gospodarczy. W 1930 r. powstał projekt nowego pensjonatu wraz z restauracją najprawdopodobniej autorstwa lokalnego architekta Maxa Zuckera ${ }^{20}$. Był on kilkakrotnie modyfikowany i poprawiany m.in. na skutek żądań Urzędu Wojewódzkiego w Stanisławowie aby architekt skoordynowat wygląd zewnętrzny fasady budynku mieszkalnego z sala restauracyjna w jedna kompozycyjna całość, gdyż w przedłożonym projekcie pawilon restauracyjny ma wyglad przybudówki ${ }^{21}$. Projekt uzyskał warunkowe pozwolenie na budowę w maju 1931 r. Kryzys ekonomiczny przeciągnął budowę pensjonatu do połowy lat 30. tamtego stulecia. Nie został przy tym zrealizowany kwestionowany „pawilon restauracyjny”. W 1935 r. Ksawera Lankoszowa (żona Władysława Lankosza) zleciła M. Zuckerowi rozbudowę pensjonatu. Zachowały się rysunki architektoniczne projektu nazwanego „Plan budowy domu dla WP. Ksawery Lankoszowej w Jamnej"22. Projekt uzyskał pozwolenie na budowę w październiku 1935 r. Architekt zaproponował rozbudowę o skrzydło niemal dosłownie powtarzające bryłę wcześniej istniejącego pensjonatu oraz zaprojektował jadalnię (restaurację) w formie parterowej przybudówki ${ }^{23}$. Możemy przeanalizować jej wygląd na podstawie oryginalnych rysunków architektonicznych (Ryc. 8, 9). Sala restauracyjna miała mieć o rzut prostokąta o wymiarach około 12 na 10 metrów i przylegać do północnej elewacji budynku. Zaplecze kuchenne zaprojektowano jako osobny parterowy pawilon połączony z salą konsumpcyjną wąskim korytarzem. O ile architektura pensjonatu utrzymana została w stylistyce regionalnej to elewacje sali jadalnianej posiadały zdecydowanie klasycyzujący charakter. Na wysokim kamiennym cokole pojawiły się półkolumny z entasis podtrzymujące profilowany gzyms zwieńczony attykową balustradą. Przedzielały one osie okienne, z których trzy centralne posiadały półkoliste zamknięcia. Koncepcja przestrzennej kompozycji wnętrza była natomiast modernistyczna i nawiązywała do poprzednio omawianej restauracji Skrzyńskiego. Centralna część sufitu pomieszczenia została podniesiona w górę, względem dwóch niższych aneksów, o około 1 metr. Zaprojektowany w ten sposób, wsparty na czterech narożnych słupach, świetlik zapewniał bezpośrednie doświetlenie środkowej części wnętrza. Boczne aneksy doświetlone były oknami umieszczonymi w ścianach parteru.
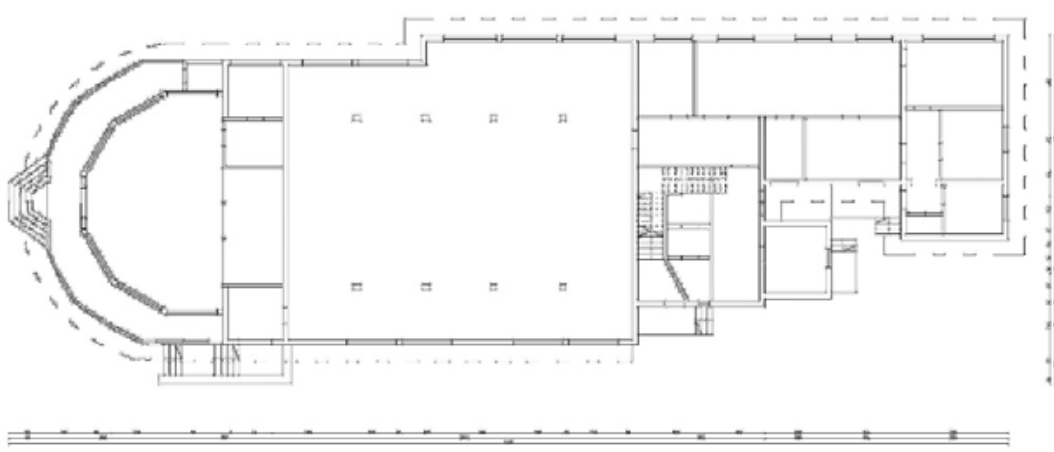

Ryc. 6. Jaremcze. Dawna restauracja Skrzyńskiego. Inwentaryzacja architektoniczna, rzut parteru. Autorzy: Studenci WA PK: Karolina Chodur, Ewelina Niemczyk i Gabriela Sobota, 2011

19 Miejscowość klimatyczna..., op. cit., s. 11.

20 Max Zucker był autorem ponad dwudziestu projektów budynków w miejscowościach uzdrowiskowych położonych w dolinie Prutu na Huculszczyźnie, Jaremczu, Tatarowie i Worochcie. Por.: J. Czubiński, Architect Max Zucker - regionalist or modernist? Designs from the Prut valley in the Hutsul region, Teka Komisji Architektury, Urbanistyki i Studiów Krajobrazowych, t. XIV, nr 2, Lublin 2018, s. 21-27. Także: Czubiński J., Nurt modernizmu..., op. cit.

21 DAIFO, sygn. 2/1e-8/2215.

22 DAIFO, sygn. 2/1e-8/2285.

23 Ibidem. 


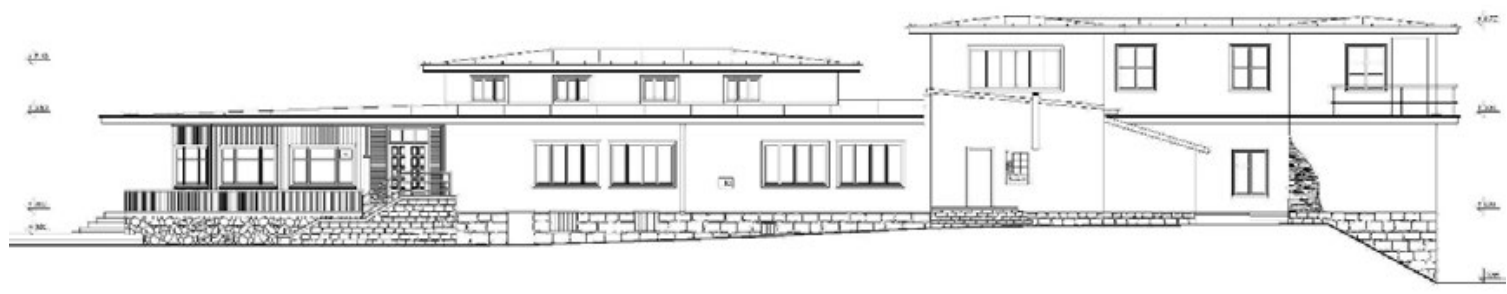

Ryc. 7. Jaremcze. Dawna restauracja Skrzyńskiego. Inwentaryzacja architektoniczna, elewacja południowa. Autorzy: Studenci WA PK: Karolina Chodur, Ewelina Niemczyk i Gabriela Sobota, 2011

Rozbudowę pensjonatu "Lankoszówka" ukończono prawdopodobnie w połowie $1936 \mathrm{r}$. Nie zrealizowano natomiast pawilonu mieszczącego omawianą poprzednio salę jadalnianą (restauracyjną). Można przypuszczać, że było to podyktowane decyzją wybudowaniu osobnego, niezależnego kubaturowo od pensjonatu, budynku restauracji. Rezygnując z usług architekta M. Zuckera inwestor powierzył wykonanie projektu budowniczemu rządowemu inżynierowi Maxymilianowi Platzerowi ze Stanisławowa. Projekt pod nazwą „Plan restauracji i sali dancingowej dla WP. Władysława Lankosza w Jamnie" został wykonany w na początku lutego 1936 r. a pozwolenie na budowę uzyskano 30 kwietnia tamtego roku².
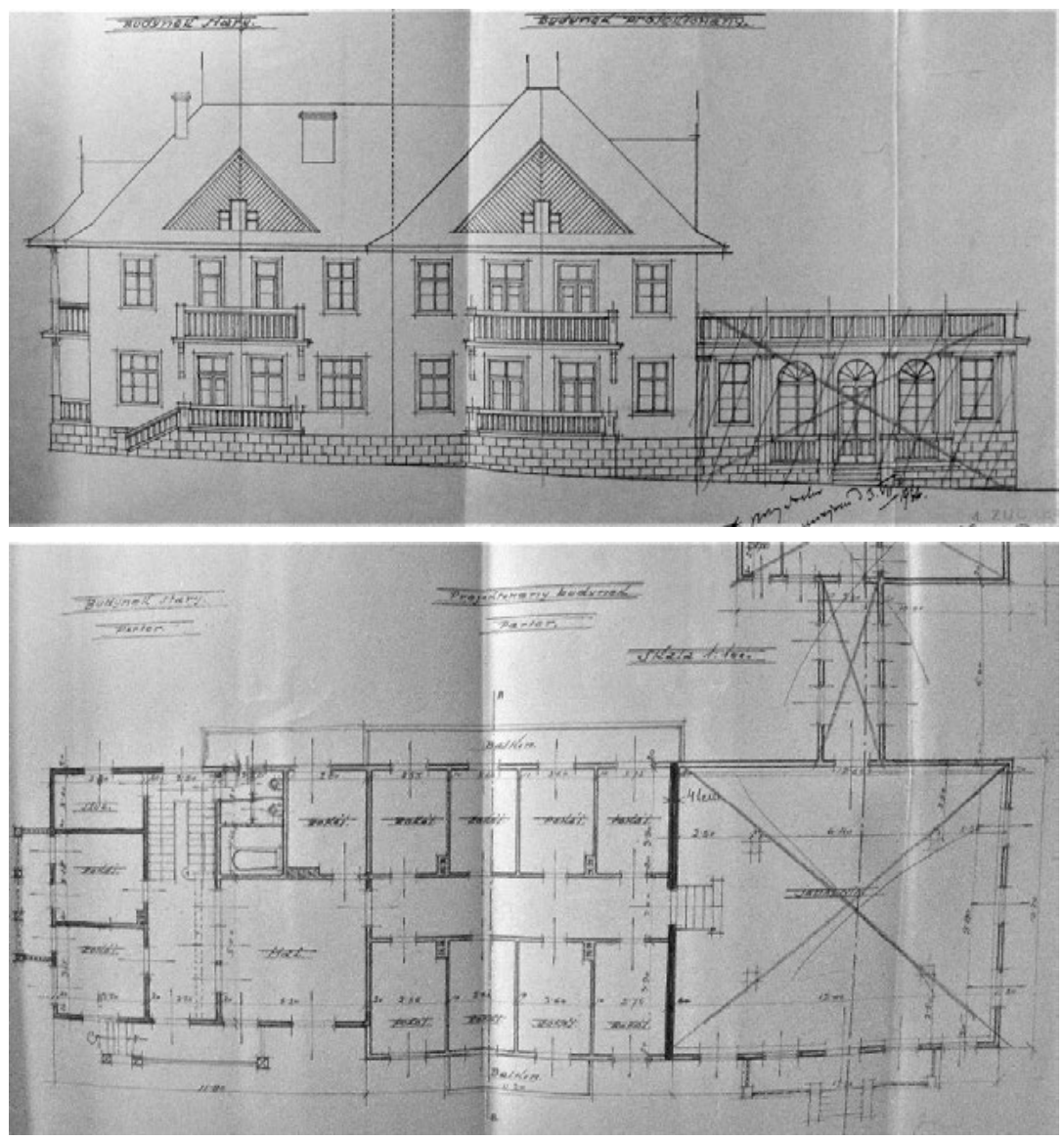

Ryc. 8. 9. Jaremcze-Jamna. Projekt rozbudowy pensjonatu Władysława Lankosza; elewacja wschodnia i rzut parteru. Autor: arch. Max Zucker, 1935 r. Po prawej stronie elewacji i rzutu niezrealizowana sala jadalniana (restauracyjna), powyżej łącznik prowadzący do zaplecza kuchennego (DAIFO, sygn. $2 / 1 \mathrm{e}-8 / 2285$ )

Budynek nowej restauracji zlokalizowano na południowy zachód od pensjonatu, być może na miejscu, wspomnianej wcześniej, wyburzonej pierwszej restauracji Lankosza (Ryc. 10,11). Rzut obiektu oparty został na planie zamkniętej podkowy (Ryc. 12). Jego zasadniczą część stanowiła sala konsumpcyjna w kształcie regularnego 
dwunastoboku z przylegającą od zachodu, częściowo podpiwniczoną, częścią kuchenno-gospodarczą od strony rzeki. Główne wejście do budynku znajdowało się w elewacji wschodniej, czyli od strony stacji kolejowej i drogi gminnej. Prowadziło ono, poprzez taras obiegający budynek, bezpośrednio do sali konsumpcyjnej. Parkiet taneczny usytuowano w centralnej części wyznaczonej przez układ dwunastu słupów podtrzymujących świetlik dachowy. Światło docierało do wnętrza poprzez pasmowe okno świetlika, co zapewniało górne doświetlenie, oraz przez duże przeszklenia ścian zewnętrznych. Niższe obejście parkietu, gdzie zlokalizowane były stoły konsumpcyjne, przykryte zostało dachem pulpitowymi. Świetlik otrzymał dach stożkowy (Ryc. 13). Toalety dla konsumentów i obsługi oraz lodownia umieszczono w dwóch niewielkich obiektach zlokalizowanych od strony Prutu, po zachodniej stronie głównego budynku. Budynek ten wykazuje bezpośrednią analogię z rozbudową wcześniej omawianej restauracji Skrzyńskiego w Jaremczu dokonaną w drugiej połowie lat 30. XX w. Na obecnym etapie badań trudno jednoznacznie stwierdzić, która z tych realizacji była pierwsza.
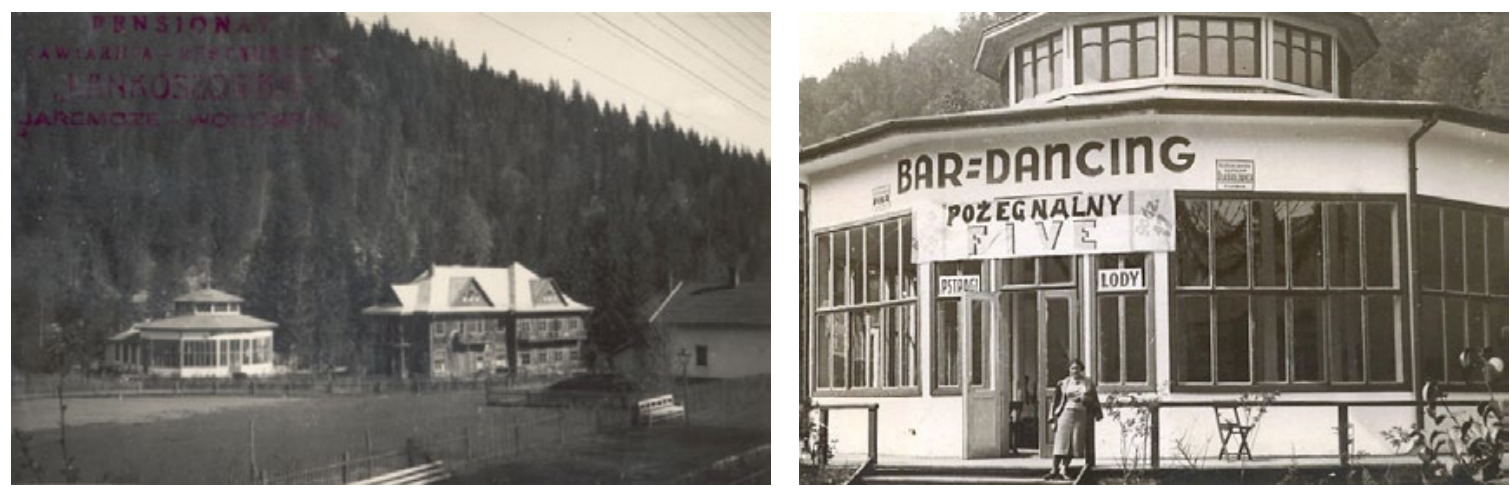

Ryc. 10. Jaremcze-Jamna. Pensjonat i restauracja Lankosza. Fotografia reklamowa z pieczątką o treści: „Pensjonat. Kawiarnia - Restauracja "LANKOSZÓWKA". Jaremcze-Worochta” 1938 r.

Ryc. 11. Jaremcze-Jamna. Restauracja Lankosza „Bar Dancing". Projektant: M. Platzer 1936 r. (Zbiory autora) (Zbiory autora)
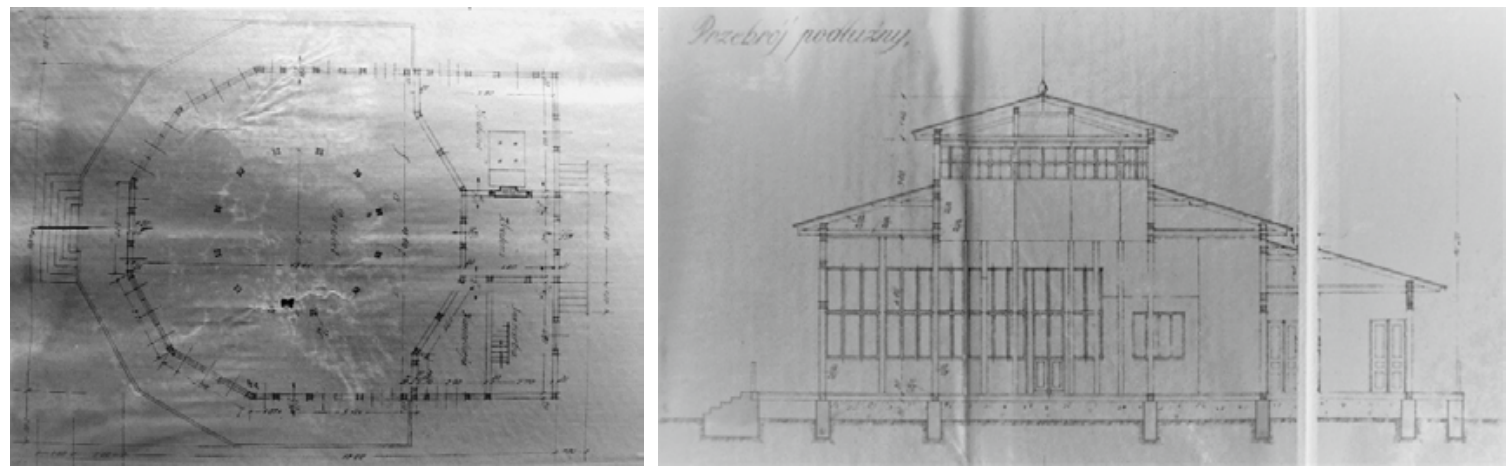

Ryc. 12. 13. Jaremcze-Jamna. Restauracja Lankosza „Bar Dancing”. Projekt „Plan restauracji i sali dancingowej dla WP. Władysława Lankosza w Jamnie", rzut i przekrój podłużny. Autor: inż. Maxymilian Platzer, 1936 (DAIFO, sygn. 2/1e-8/2452)

Kompozycja bryły sali konsumpcyjnej „Lankoszówki” przypomina niewielkie pawilony powstające okazjonalnie przy okazji różnego rodzaju wystaw. Łączy je m.in. układ rzutu, jednokondygnacyjność oraz analogiczne, „bazylikowe” rozwiązanie doświetlenia centralnego pomieszczenia. Często były to pawilony gastronomiczne. Bardzo podobny układ wnętrza widać w rotundzie pawilonu polskiego na światowej wystawie Sztuki Dekoracyjnej i Wzornictwa w Paryżu w 1925 autorstwa Józefa Czajkowskiego ${ }^{25}$. Przykładem podobnego formalnie rozwiązania może być okrągły w rzucie, przeszklony pawilon „Dancing i Kabaret” na Powszechnej Wystawie 
Krajowej w Poznaniu w 1929 r. Projektantem tego obiektu był arch. Jerzy Müller, eksperymentalną drewnianą konstrukcję łukową zaprojektował inż. Ludwik Paradistal ${ }^{26}$.

Zarówno pensjonat jak i restauracja Lankoszów nie zachowały się do dnia dzisiejszego. Nie znane są daty ani okoliczności zniszczenia tych obiektów.

Przedstawione powyżej przykłady budynków restauracji Skrzyńskiego i Lankosza związane były z nurtem architektury modernistycznej. Jak wspomniano na wstępie, nie była to tendencja dominująca w międzywojennej architekturze regionu. Przeważały obiekty utrzymane w stylistyce regionalnej - huculskiej i zakopiańskiej lub łączącej te tendencje. Poniżej zaprezentowane zostaną dwa przykłady takich obiektów. Należy zauważyć, że obok nich, znane są inne interesujące przykłady regionalnego wystroju wnętrz pensjonatowych i willi prywatnych. Do najciekawszych, niestety niezachowanych, należy zaliczyć niektóre wnetrza pensjonatu "Straszny Dwór" i domu prywatnego Jana Romaszkana w Tatarowie ${ }^{27}$. Drewniany strop kasetonowy o cechach huculsko-zakopiańskich zachował się w dawnym pomieszczeniu apteki w pensjonacie zlokalizowanym przy ul. Daniła Halickiego 61 w Worochcie.

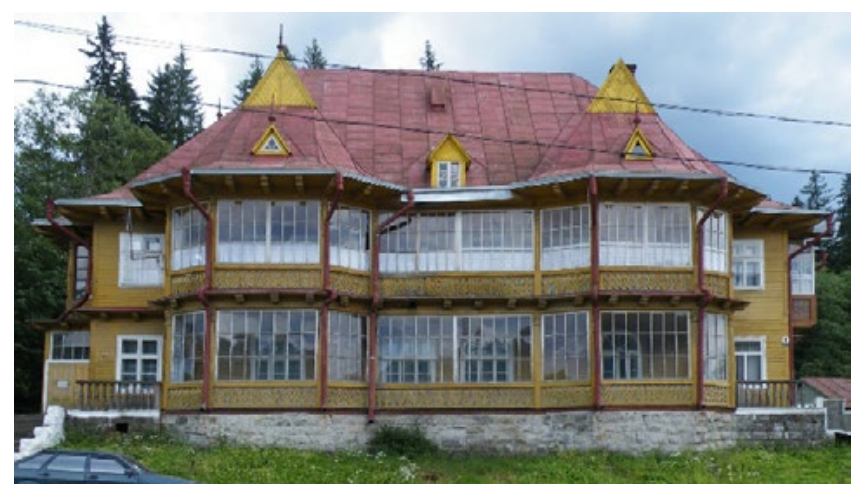

Ryc. 14. Worochta. Dawny pensjonat „Liliana”. Elewacja zachodnia (Fotografia autora, 2009 r.)

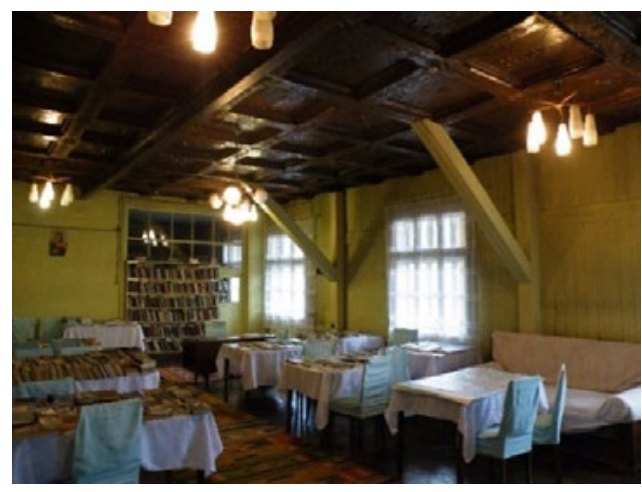

Ryc. 15. Worochta. Dawny pensjonat „Liliana”. Wnętrze dawnej jadalni ze stropem kasetonowym, boazerią i wtórnymi zastrzałami (Fotografia autora, 2009 r.)

Interesującym obiektem reprezentującym lokalny regionalizm jest dawny pensjonat "Liliana" w Worochcie (Ryc. 14). Obecnie mieści się w nim biblioteka pobliskiego sanatorium "Górskie Powietrze" - w okresie międzywojennym było to Sanatorium Kasy Chorych. Zlokalizowany jest w północnej części Jaremcza przy ulicy Daniła Halickiego 5. Jest drewnianym, piętrowym budynkiem o planie opartym na rzucie litery "L" ze stromym wielopołaciowym, pokrytym blachą dachem. W południowej, zachodniej i północnej elewacji występują dwukondygnacyjne, pierwotnie otwarte, obecnie przeszklone werandy. Elewacja wschodnia posiada werandy w kondygnacji I piętra. Obiekt powstał najprawdopodobniej w drugiej połowie lat 30. XX w., nieznany jest jego projektant ${ }^{28}$.

W niektórych wnętrzach budynku zachował się ich oryginalny drewniany wystrój architektoniczny. Szczególnie starannie została zaprojektowana dawna jadalnia pensjonatu ${ }^{29}$. Jest to duże o wymiarach 6,5×10,3 m., prostokątne w rzucie, pomieszczenie zlokalizowane na kondygnacji parteru (Ryc. 15). Jego trzy okna skierowane są na wschód. Snycerska dekoracja wnętrza występuje zarówno na suficie jak i na wszystkich ścianach. Elementy stropu kasetonowego posiadają bogatą dekorację geometryczną i roślinną o regionalnych motywach zakopiańskich i huculskich. Występuję ona w profilowanych belkach stropowych oraz w polach kasetonów (Ryc. $16,18,19)$. Na podniebieniach profilowanych belek umieszczono kryształowo cięte romby i trójkąty z ukośną kratką ("mirwa”) a w ich skrzyżowaniach rozety w postaci sześciodzielnego kwiatu w otoku. Pola kasetonów wypełniają wygięte gałązki z podłużnymi liśćmi („gaje”) otaczające centralnie usytuowane sześciodzielne kwiaty

26 St. Woźnicki, Zabudowa terenów Powszechnej Wystawy Krajowej w Poznaniu, Architektura i Budownictwo, nr 1/1929, s. 1-33.

27 Por.: J. Czubiński, Straszny Dwór..., op. cit.

28 W latach 2009 oraz 2019 wykonana została częściowa inwentaryzacja obiektu. Autorami jej byli studenci z Wydziałów Architektury Politechniki Krakowskiej (PK) oraz Państwowego Uniwersytetu Technicznego Nafty i Gazu w Iwano-Frankiwsku (DTUNiG).

29 W trakcie wykonywania badań i inwentaryzacji nie wszystkie pomieszczenia budynku były dostępne. Należy przypuszczać, że dekoracja istnieje także w innych pomieszczeniach. 
(„gwiazdy”). Ściany pomieszczenia wyłożone są profilowanymi pionowymi listwami. W około 4/5 ich wysokości występuję pozioma deska dekorowana poziomym ornamentem geometrycznym analogicznym do belek stropowych. Jest on rytmicznie rozdzielany kompozycją składającą się z sześciodzielnego kwiatu zwieńczonego dwoma owalnymi, o dekoracji przypominającymi pisanki, motywami. W chwili obecnej ściany pomalowane są białą farbą olejną. Kontrastuje ona z ciemnobrązową kolorystyką stropu. Pomiędzy oknami znajdują się, przylegające do ścian zewnętrznych, dwa drewniane słupy z nieproporcjonalnie dużymi zastrzałami podtrzymującymi belki stropowe. Pod sufitem, wzdłuż pomieszczenia, umieszczona jest drewniana belka o funkcji sosrębu. Elementy te nie posiadają żadnej dekoracji snycerskiej. Bez wątpienia są to wtórne dodatki konstrukcyjne powstałe po drugiej wojnie światowej w celu przeniesienia dodatkowych obciążeń stropu związanych ze zmiana funkcji obiektu na bibliotekę.
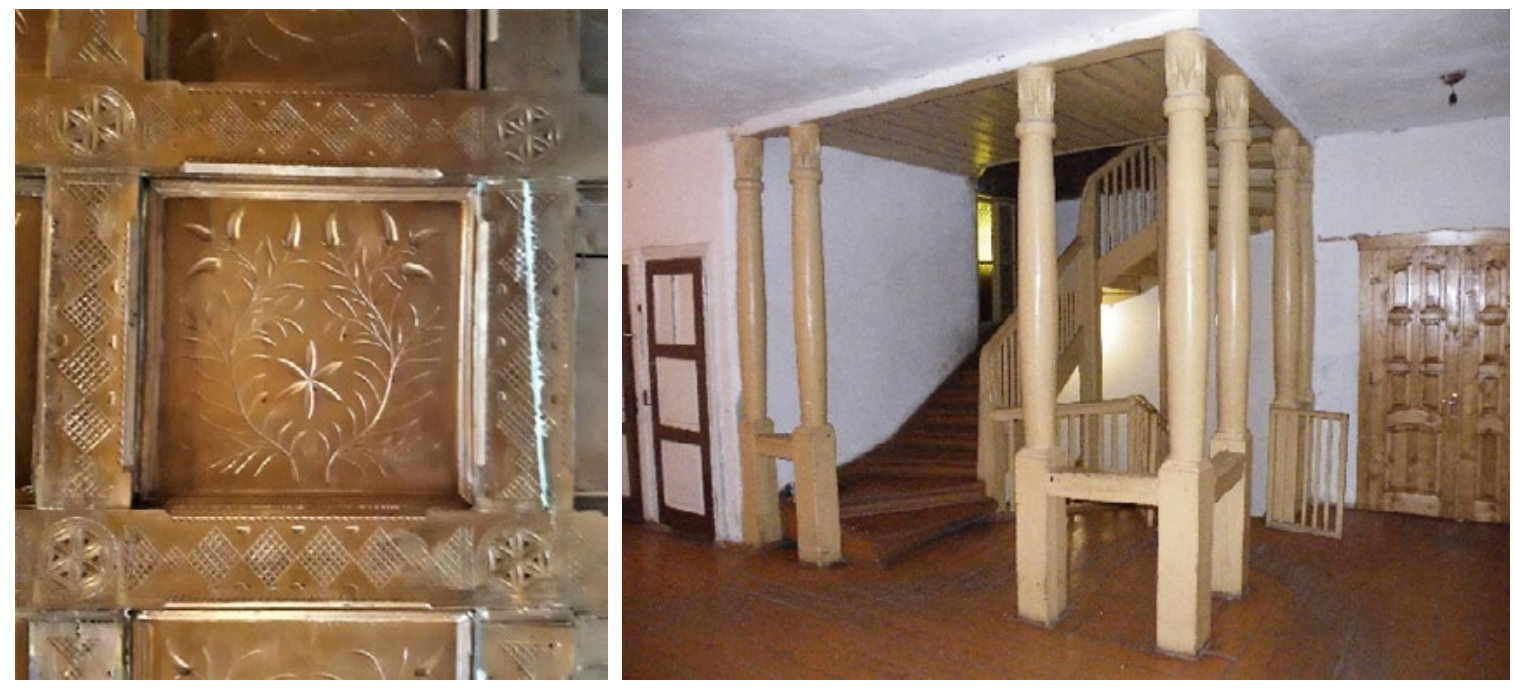

Ryc. 16. 17. Worochta. Dawny pensjonat „Liliana”. Fragment kasetonowego stropu jadalni oraz klatki schodowej na kondygnacji parteru (Fotografie autora, 2019 r.)
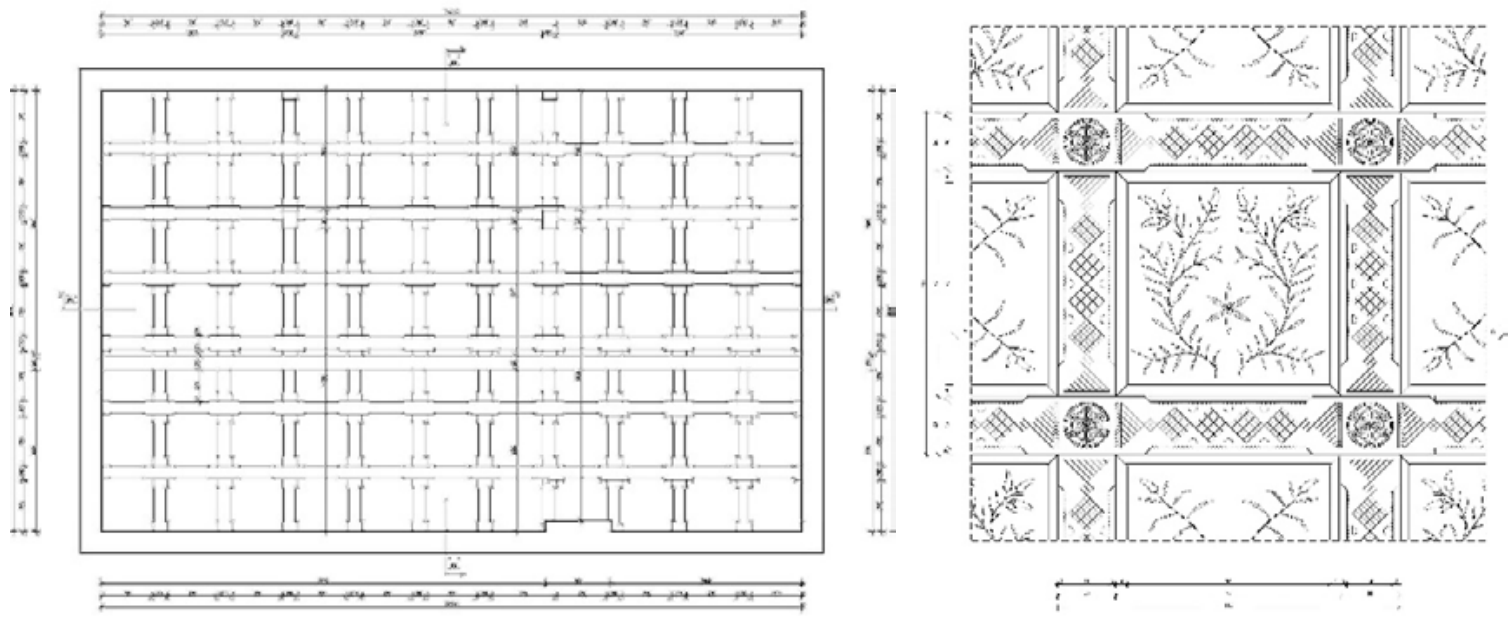

Fig. 18. 19. Worochta. Dawny pensjonat "Liliana", parter. Inwentaryzacja stropu kasetonowego dawnej jadalni, rzut i detal, 2019. Autorzy: Wika Kapelist (DTUNiG) oraz Martyna Socha (PK)

Podobny strop kasetonowy o cechach huculsko-zakopiańskich zachował się w dawnym pomieszczeniu apteki w pensjonacie zlokalizowanym przy ul. Daniła Halickiego 61 w Worochcie. 
Należy także wspomnieć o dekoracji klatki schodowej tego pensjonatu. Jej spoczniki podpierane są przez okrągłe kolumny z entasis i kryształkowo ciętymi kapitelami. Wsparte są one na kwadratowych w przekroju postumentach (Ryc. 17). Analogiczne kolumny pojawiają się jako podpory werand parteru i pierwszego piętra. Te ostatnie otrzymały także ornament kryształkowy w około 2/3 swych wysokości. Regionalnie profilowane są kroksztyny gzymsu między kondygnacją parteru i piętra oraz belek podokapowych. Balustrady werand posiadają laubzegowo ciętą dekorację geometryczną. Kryształową motywy pojawiły się na elewacjach w blaszanych zwieńczeniach rur spustowych.
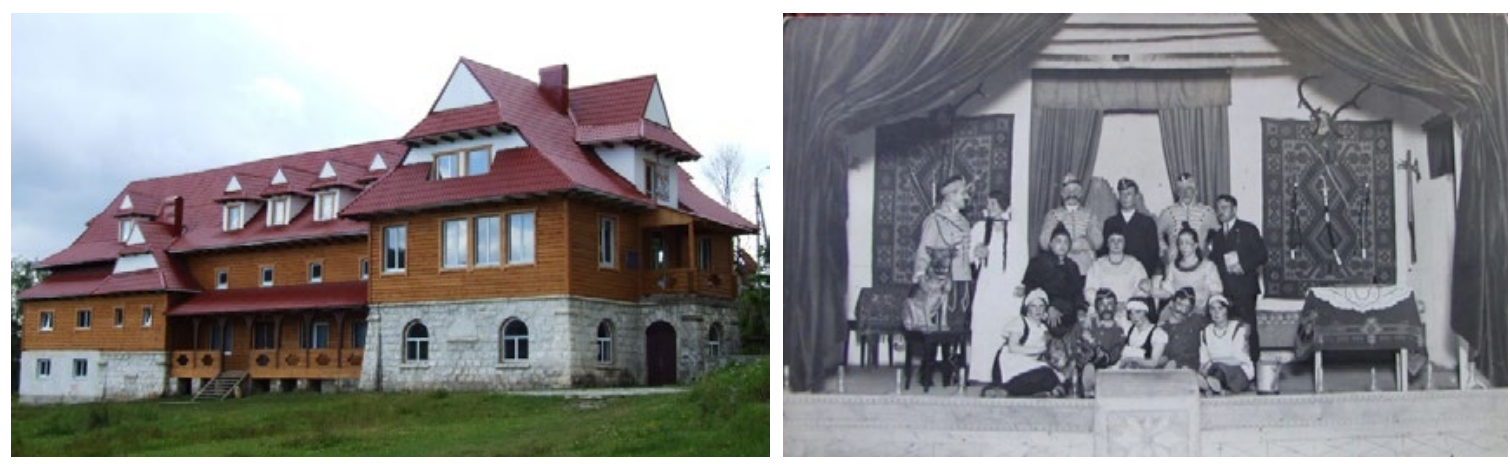

Ryc. 20. Worochta. Dawny Dom Ludowy. Widok od południowego wschodu. (Fot. autora, 2009 r.)

Ryc. 21. Worochta. Dawny Dom Ludowy. Aktorzy spektaklu „Damy i Huzary” reżyserowanego przez Kajetana Petrowicza na scenie sali widowiskowej w dniu 3.05.1933 r. U dołu widoczny fragment portalu scenicznego z regionalną ornamentyką i „kwiatem szarotki" w centrum. Zbiory Krystyny Petrowicz-Szopa. Źródło: http://www.wiki.ormianie.pl/index.php?title=Kajetan_Petrowicz_syn_Marko (Dostęp 11.10.2020)

Cechy stylu zakopiańskiego widoczne są w kompozycji bryły i detalach elewacji budynku dawnego Domu Ludowego, obecnie Domu Kultury w Worochcie, usytuowanego w południowej części miejscowości, przy ulicy Daniła Halickiego ${ }^{30}$ (Ryc. 20). W części wschodniej i zachodniej jest to obiekt piętrowy, natomiast jednokondygnacyjna jest partia centralna mieszcząca salę widowiskową. Posiada użytkowe poddasze. Plan oparty jest na rzucie prostokąta z ryzalitami. Parter wykonany jest ciosów kamiennych, wyższe kondygnacje są drewniane o konstrukcji zrębowej. Ściany zostały obite poziomymi deskami w 2006 r. W szczytach występowały motywy wschodzącego słońca ("słoneczka”). Zarówno one jak i okapy międzykondygnacyjne świadczą o wpływach architektury Podhala ${ }^{31}$. Obiekt powstał pomiędzy 1926 a 1929 r. z inicjatywy Towarzystwa Szkoły Ludowej ${ }^{32}$, współfinansowany był ze składek społecznych. Mieściła się w nim m.in. biblioteka z czytelnią, organizowano tam różnego typu spotkania i uroczystości a także działał teatr amatorski (Ryc. 21). Teatr został założony około 1930 r. przez mieszkańców Worochty: polskiego Ormianin Kajetana Petrowicza oraz dwie nauczycielki, siostry - Marię i Jadwigę Czuprówny ${ }^{33}$. Przedstawienia reżyserował Kajetan Petrowicz ${ }^{34}$. Był on m.in. działaczem Towarzystwa Szkoły Ludowej i współinicjatorem budowy Domu Ludowego. Przypisywane jest mu także autorstwo projektu architektonicznego tego obiektu ${ }^{35}$. Tworzył poezję publikowaną w okresie międzywojennym we Iwowskim czasopiśmie „Posłaniec św. Grzegorza" ${ }^{36}$. Jego autorstwa był także, zebrany w 1967 r., maszynopisany

30 W latach 2016 oraz 2019 wykonana została częściowa inwentaryzacja obiektu. Autorami jej byli studenci z Wydziałów Architektury Politechniki Krakowskiej (PK) oraz Państwowego Uniwersytetu Technicznego Nafty i Gazu w Iwano-Frankiwsku (DTUNiG).

31 Budynek rozbudowano, najprawdopodobniej w końcu I. 30. XX w., w kierunku zachodnim o zaplecze sceny. Ostatnia modernizacja z około 2006 r. pozbawiła go wielu oryginalnych detali elewacyjnych.

32 Towarzystwo Szkoły Ludowej było organizacją oświatową powstałą w 1891 r. w Galicji, istniała do 1940 r. Zakładała i budowała m.in. szkoły domy ludowe, biblioteki i czytelnie. Organizowała pracę nauczycieli. W okresie międzywojennym działała w południowych i wschodnich województwach II Rzeczypospolitej.

33 I. Błaż, Moje Kresy. Opowieści Czarnohorskie, "Nowa Trybuna Opolska”, 9 i 18.01.2013.

34 S. Nicieja, Moje Kresy. Opowieści Czarnohorskie, "Nowa Trybuna Opolska”, 19.01.2013.

35 Twierdzi tak jego córka Krystyna Petrowicz-Szopa. Kajetan Petrowicz był inżynierem budownictwa. Por.: http://www.wiki.ormianie.pl/index. php?title=Kajetan_Petrowicz_syn_Marko [dostęp 28.01.21].

36 Czasopismo to powstało we Lwowie w 1927 r., od 1930 r. stało się oficjalnym organem Ormian polskich skupionych w pierwszej w Polsce organizacji ormiańskiej Archidiecezjalnym Związku Ormian. Por.: D. Skotarczak, Czasopisma ormiańskie w Polsce, "Zeszyty Prasoznawcze", T. 57, nr 3(219) 2014, s. 528 . 
zbiór poezji pt. „Z przeszłości górnej i chmurnej. Obrazki z życia Ormian polskich" ${ }^{37}$. K. Petrowicz mieszkał nieopodal Domu Ludowego, będącym jego własnością, wybudowanym około 1930 r. wg własnego projektu, pensjonacie "Ustronie" ${ }^{38}$.
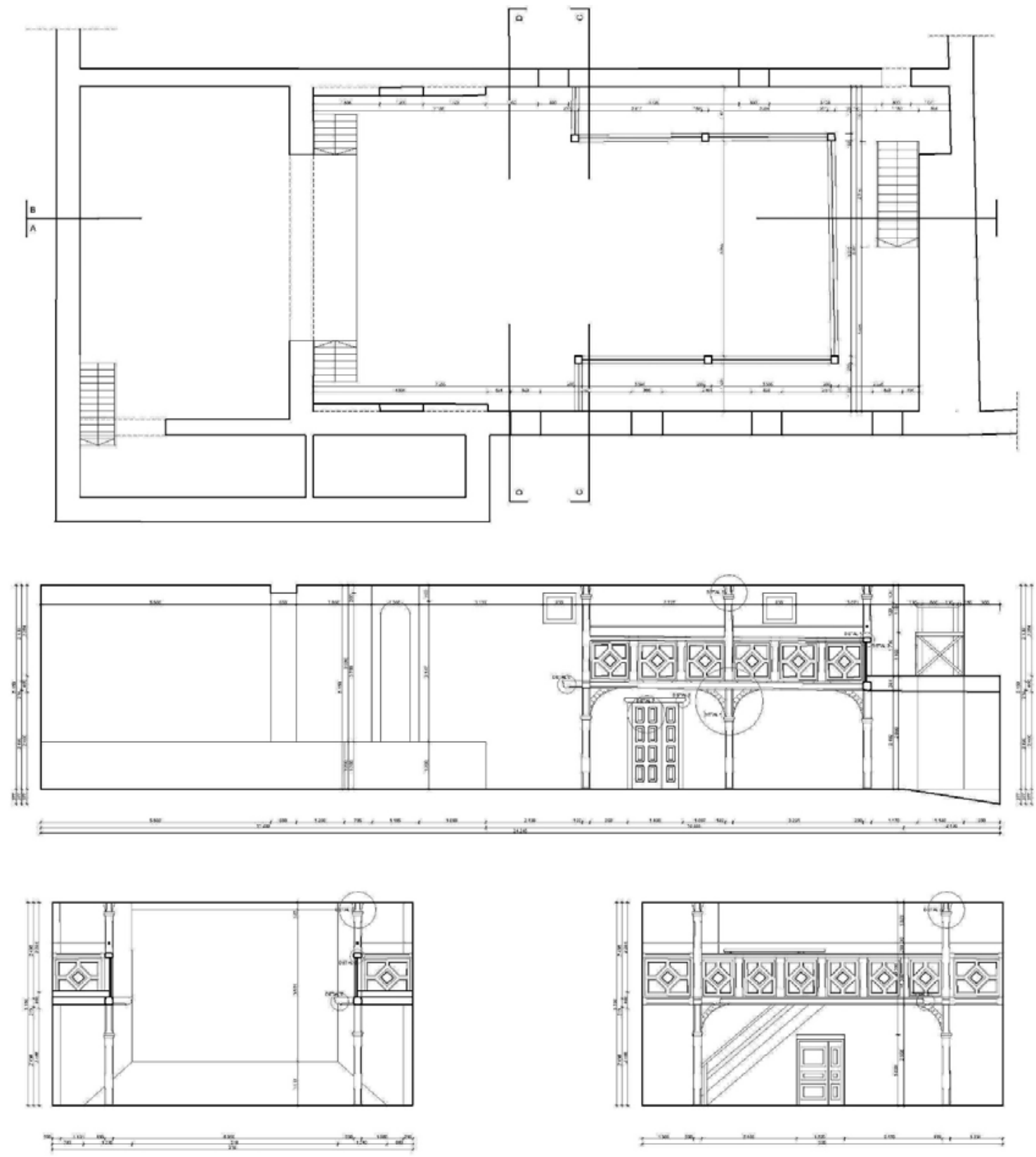

Ryc. 22. 23. 24. Worochta. Dawny Dom Ludowy. Inwentaryzacja architektoniczna wnętrza sali widowiskowej: rzut na poziomie antresoli, przekrój podłużny, przekroje poprzeczne. Autorzy: Julia Sierpień, Joanna Ślipko, Ruslan Antalovtsi, Dmytro Petruk (studenci PK i DTUNiG), $2019 \mathrm{r}$. 
W centralnej części Domu Ludowego usytuowana jest duża sala widowiskowa ze sceną (Ryc. 22, 23, 24). W niej odbywały się wspomniane przedstawienia teatralne. Pierwotnie prostokątna z płytką sceną od zachodu została, prawdopodobnie przed 1939 r., powiększona o zascenie. Od południa i północy doświetlona jest oknami. Zewnętrzne drzwi prowadzą na drewniany podcień usytuowany w południowej elewacji budynku. Wewnątrz sali znajduje się, wsparta na słupach z zastrzałami, drewniana antresola na planie litery "U". Obiega ona wschodnią część pomieszczenia. Oryginalnie sala było wyższa niż obecnie. Wspomniane słupy wspierają także, zakryty obecnie płaskim sufitem podwieszonym, strop pomieszczenia o nierozpoznanym kształcie. Profile elementów konstrukcyjnych, kształt zastrzałów i inne detale nawiązują do podhalańskiej i huculskiej architektury regionalnej. Ściany do wysokości około półtora metra posiadały drewnianą boazerię z geometrycznym wzorem zbudowanym z białych kwadratów i prostokątów skontrastowanych z ciemnym kolorem tworzących je drewnianych ram. Podobną zasadę alternacji barwnej zastosowano w balustradach antresoli. Podziały są tutaj bardziej dynamiczne, bowiem centralny kwadrat kompozycji jest obrócony o kąt 90 stopni. Obecnie pomieszczenie to, zachowując układ przestrzenny, utraciło swój oryginalny wygląd. Brak boazerii, obniżony, przemysłowy w formie sufit oraz nowa kolorystyka spowodowały częściową utratę regionalnego wystroju wnętrza.
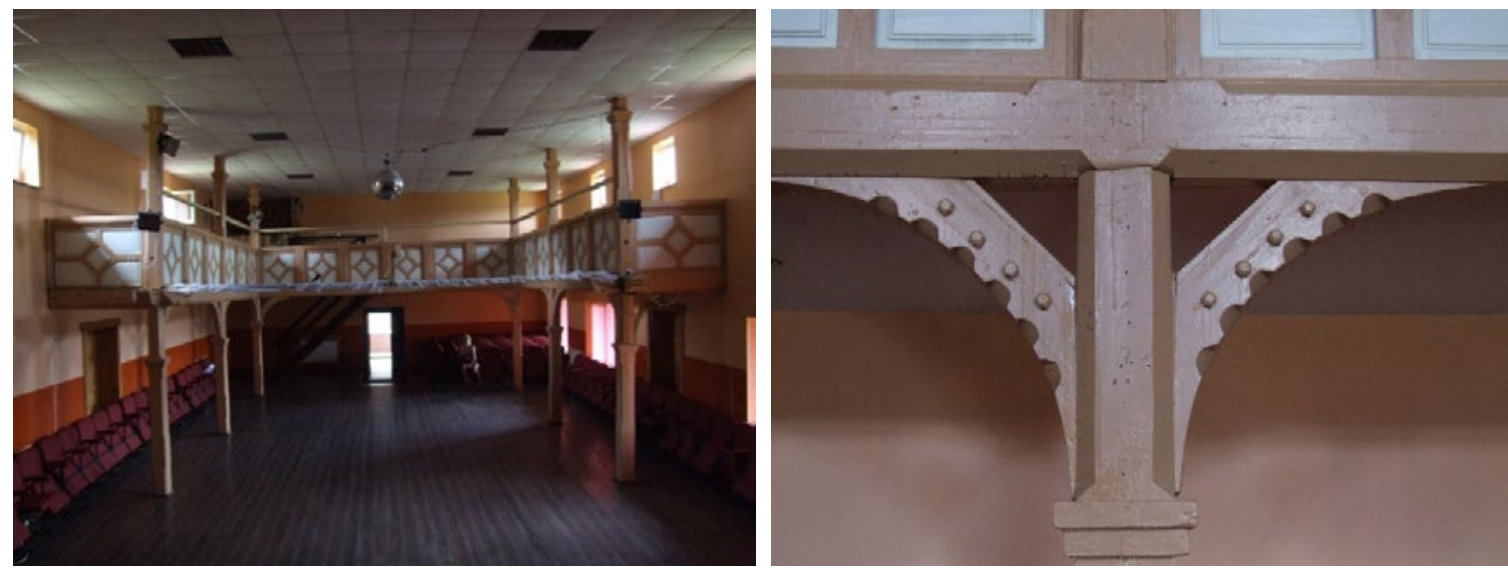

Ryc. 25. 26. Worochta. Dawny Dom Ludowy. Wnętrze sali widowiskowej oraz zastrzał podtrzymujący antresolę (Fot. autora, 2019)

\section{Wnioski}

W chwili obecnej historyczne wnętrza ulegają ciągłej modernizacji zacierającej ich oryginalny wystrój. Zniszczeniu ulegają zarówno całe zespoły kompozycyjne pomieszczeń jak i ich detale. Większość dawnych pensjonatów została po Il wojnie światowej przekształcona w wielorodzinne domy mieszkalne. Ich wnętrza podzielono na niewielkie lokale kwaterunkowe, co związane było z zanikiem pierwotnego układu pomieszczeń. Wizualnie atrakcyjne elementy wyposażenia lub wystroju bywają, często świadomie, niszczone, usuwane lub przenoszone na nowe miejsce ${ }^{39}$.

Jak wcześniej wspomniano, zagadnienie wystroju wnętrz historycznych było niemal całkowicie pominięte w dotychczasowych badaniach nad architekturą tego regionu. Pewnym jest, że warte uwagi wnętrza zostaną zidentyfikowane w przyszłości w innych, nie omawianych w tej pracy obiektach. W dawnych pensjonatach ze szczególną troską opracowywano pomieszczenia wspólnego użytkowania gości, takie jak sienie wejściowe, jadalnie czy klatki schodowe. Zwykle wystrój w poszczególnych obiektach różnił się od siebie m.in. kształtem i profilowaniem belek i słupów oraz dekoracją snycerską. Jednocześnie występowała, w trudnej do określenia w chwili obecnej skali, pewna standaryzacja i powtarzalność elementów wystroju. Zauważyć bowiem trzeba, że belkowe stropy kasetonowe w pensjonacie "Liliana” oraz wspomnianym wcześniej pensjonacie z apteką (obydwa położone w Jaremczu) wykonane są wg jednego wzoru. Zindywidualizowane były wnętrza obiektów 
użyteczności publicznej np. dworców kolejowych czy też sanatoriów. W projektowanych w drugiej połowie lat. 30. XX wieku modernistycznych salach restauracyjnych zauważyć widać popularność "bazylikowego" układu przestrzeni wnętrza.

Opracowanie i analiza stylistyki aranżacji wnętrz, stosowanych motywów ornamentalnych, detali i profilów czy też kolorystyki wydaje się zagadnieniem ważnym z kilku powodów. Umożliwi pogłębienie wiedzy o odrębności formalnej i kompozycyjnej architektury tego regionu. Jest to szczególnie ważne w kontekście jego autonomii stylistycznej w relacji do "stylu galicyjskiego" propagowanego od końca 19. wieku przez Edgara Kovácsa. Należy też przypuszczać, że takie badania doprowadzą do pełniejszego wyodrębnienia cech lokalnego stylu huculskiego. Niejednokrotnie bowiem zacierają się różnice pomiędzy tą tendencją a, często obecną w Karpatach Wschodnich zakopiańszczyzną rodem z Podhala. Niezbędnym jest więc prowadzenie dalszych studiów, w których zagadnienie wystroju historycznych wnętrz będzie ich bardzo istotnym elementem.

\section{Podsumowanie}

W ostatnich latach nasilił się proces dewastacji historycznych obiektów w dolinie rzeki Prut na Huculszczyźnie. Rozwijający się ruch turystyczny związany m.in. ze zlokalizowaną w pobliskim Bukowelu olbrzymią stacją narciarską wpłynął na gwałtowny wzrost cen gruntu. Stare, drewniane budynki nie spełniają współczesnych norm i z trudnością spełniają oczekiwania nowych właścicieli. Nie są one objęte ochrona konserwatorską, co powoduje ich wyburzanie i powstawanie na ich miejscu nowych obiektów. Wydaje się, że z uwagi na ograniczenia prawne i organizacyjne proces ten jest niemożliwy do zatrzymania. Jedynie w ostatnim dziesięcioleciu uległo całkowitemu zniszczeniu kilkanaście cennych obiektów. Rozebrane zostały m.in.: pensjonaty "Raj”, Maraton” i dwa inne w zespole "Morskie Oko" w Jaremczu oraz "Mela" w Worochcie. W stanie całkowitej ruiny znajduje się jeden z najstarszych obiektów Jaremcza - duży pensjonat "Dwór". Spaleniu uległy dwa niezwykle interesujące obiekty w Worochcie: „Pod Matką Boską" oraz "Halina”.

W kontekście omawianej problematyki pilną potrzebą jest zlokalizowanie i wykonanie inwentaryzacji rysunkowych oraz dokumentacji fotograficznej jak największej ilości zarówno całych budynków jak i ich najistotniejszych wnętrz. Wspomniany wcześniej, rozpoczęty wiele lat temu polsko-ukraiński program takich badań będzie kontynuowany w przyszłości.

\section{Wybrana literatura i źródła}

[1] Archiwum Fundacji Kultury i Dziedzictwa Ormian Polskich, sygn. 161.

[2] Czubiński, Architect Max Zucker - regionalist or modernist? Designs from the Prut valley in the Hutsul region, "Teka Komisji Architektury, Urbanistyki i Studiów Krajobrazowych", t. XIV, nr 2, Lublin 2018.

[3] Czubiński J., Nurt modernizmu w międzywojennej architekturze miejscowości uzdrowiskowych położonych w dolinie rzeki Prut na Huculszczyźnie, [w:] „Modernizm w Europie - Modernizm w Gdyni”, Gdynia 2018.

[4] Czubiński J., Straszny Dwór (Haunted Manor) guesthouse in Tatarów in the Hutsul region and its designer Jerzy Romaszkan, "Teka Komisji Architektury, Urbanistyki i Studiów Krajobrazowych", t. 13, nr 3, Lublin 2017, s. 67-77.

[5] Błaż I., Moje Kresy. Opowieści Czarnohorskie, Nowa Trybuna Opolska, 9 i 18.01.2013.

[6] Drohobycka-Grzesiak W., Architektura uzdrowisk wschodniokarpackich w okresie międzywojennym i jej stan obecny (na postawie wybranych przykładów, [w:] Architektura XX wieku i jej waloryzacja w Gdyni i w Europie. Modernizm w Europie, Modernizm w Gdyni. Tom 4, Gdynia 2017, s. 157-162. Lewicki St. A., Orłowicz M., Praschil T., Przewodnik po zdrojowiskach i miejscowościach klimatycznych Galicyi, Lwów 1912.

[7] Narodowe Archiwum Cyfrowe, różne syfnatury.

[8] Nicieja St. S., Kresowa Atlantyda. Historia i mitologia miast kresowych. T. II. Uzdrowiska i letniska kresowe. Truskawiec, Jaremcze, Worochta, Skole, Morszyn, Opole 2013.

[9] Nicieja St. S., Moje Kresy. Opowieści Czarnohorskie, "Nowa Trybuna Opolska”, 19.01. 2013. Państwowe Archiwum Iwano-Frankiwskiej Oblastii w Iwano-Frankiwsku (DAIFO), różne sygnatury.

[10] Petrowicz T., Od Czarnohory do Białowieży, Lublin 1986.

[11] Skłodowski J., Niezwykty album Zygmunta Chudzikiewicza. Część I, „Kurier Galicyjski”, nr 21 (313) 16-19.11.2020, s. 20. 
[12] Skotarczak D., Czasopisma ormiańskie w Polsce, "Zeszyty Prasoznawcze”, t. 57, nr 3(219) 2014, s. 526-535.

[13] „Wiadomości Turystyczne”, 1.06.1937, rok VII, nr 11.

[14] Woźnicki St., Zabudowa terenów Powszechnej Wystawy Krajowej w Poznaniu, "Architektura i Budownictwo”, nr 1/1929.

\section{Stylistic trends in historic interiors of buildings located in selected spa towns in the Hutsul region - an outline of the issues}

Abstract: In the spa towns located in the Prut valley in the Hutsul region, a large, extremely interesting complex of facilities built in the interwar period has been preserved. They are associated with both modernist architecture and regional trends. The work presents and analyses selected examples of interior design representing these two trends. This issue has been almost completely ignored in previous research on the architecture of this region. The field and archival studies conducted by the author made it possible to identify a number of projects and implementations. Research will be continued in the future.

Keywords: spa architecture, Hutsul region, historical interiors, Vorokhta, Yaremche 